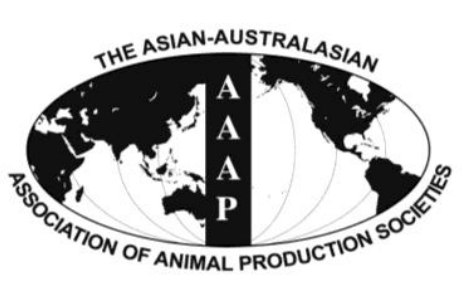

Open Access

Asian Australas. J. Anim. Sci.

Vol. 28, No. 2 : 171-179 February 2015

http://dx.doi.org/10.5713/ajas.14.0329

www.ajas.info

pISSN 1011-2367 elSSN 1976-5517

\title{
Zearalenone Altered the Serum Hormones, Morphologic and Apoptotic Measurements of Genital Organs in Post-weaning Gilts
}

\author{
X. X. Chen, C. W. Yang ${ }^{1}$, L. B. Huang, Q. S. Niu, S. Z. Jiang*, and F. Chi ${ }^{2}$ \\ Department of Animal Sciences and Technology, Shandong Agricultural University, \\ Tai'an, Shandong 271018, China
}

\begin{abstract}
The present study was aimed at investigating the adverse effects of dietary zearalenone (ZEA) (1.1 to $3.2 \mathrm{mg} / \mathrm{kg}$ diet) on serum hormones, morphologic and apoptotic measurements of genital organs in post-weaning gilts. A total of twenty gilts (LandracexYorkshirexDuroc) weaned at $21 \mathrm{~d}$ with an average body weight of $10.36 \pm 1.21 \mathrm{~kg}$ were used in the study. Gilts were fed a basal diet with an addition of $0,1.1,2.0$, or $3.2 \mathrm{mg} / \mathrm{kg}$ purified ZEA for $18 \mathrm{~d}$ ad libitum. Results showed that $3.2 \mathrm{mg} / \mathrm{kg}$ ZEA challenged gilts decreased $(\mathrm{p}<0.05)$ the serum levels of luteinizing hormone, however, serum levels of prolactin in gilts fed the diet containing 2.0 $\mathrm{mg} / \mathrm{kg}$ ZEA or more were increased ( $\mathrm{p}<0.05)$ compared to those in the control. Linear effects on all tested serum hormones except progesterone were observed as dietary ZEA levels increased $(\mathrm{p}<0.05)$. Gilts fed ZEA-contaminated diet showed increase $(\mathrm{p}<0.05)$ in genital organs size, hyperplasia of submucosal smooth muscles in the corpus uteri in a dose-dependent manner. However, the decreased numbers of follicles in the cortex and apoptotic cells in the ovarian were observed in gilts treated with ZEA in a dose-dependent manner. Degeneration and structural abnormalities of genital organs tissues were also observed in the gilts fed diet containing $1.1 \mathrm{mg} / \mathrm{kg}$ ZEA or more. Results suggested that dietary ZEA at 1.1 to $3.2 \mathrm{mg} / \mathrm{kg}$ can induce endocrine disturbance and damage genital organs in postweaning gilts. (Key Words: Zearalenone, Gilt, Hormones, Morphology, Apoptosis)
\end{abstract}

\section{INTRODUCTION}

It has been previously reported that severe contamination of grain and feed with zearalenone (ZEA) occurs in numerous areas of the world (Chaytor et al., 2011). The laggard harvest conditions of grain and the processing of edible oil significantly aggravated the contamination by fusarium in China, and the contamination levels of mycotoxins such as ZEA were much higher than those in other countries (Zhang et al., 1997).

Pigs are the most sensitive species to ZEA (EFSA, 2004), and the main toxicities of ZEA and its metabolites were caused by their activities of estrus hormones and anabolism (Etienne and Jemmali, 1982). Zearalenone could

\footnotetext{
* Corresponding Author: Shuzhen Jiang. Tel: +86- 18653817377, Fax: +86-0538-8249371, E-mail: shuzhen305@163.com

${ }^{1}$ College of Life science, Shandong Agricultural University, Tai'an, Shandong 271018, China.

${ }^{2}$ Amlan International, Chicago, IL 60604, USA.

Submitted May 7, 2014; Revised Jul. 28, 2014; Accepted Sept. 5, 2014
}

induce hyperestrogenism in pigs, with typical clinical symptoms including swollen vulva (Alexopoulos, 2001), vaginal prolapsed (Blaney et al., 1984), as well as reproductive disorders such as infertility, miscarriage and false estrus in sows (Etienne and Jemmali, 1982; Price et al., 1993). Notwithstanding, the effects of ZEA on endocrine disturbance, morphology and apoptosis of reproductive organs had been well established in sows (Chang et al., 1979; Yang et al., 1994), experimental animals (Milano et al., 1995; Kaliamurthy et al., 1997; Mitak et al., 2001) and cultured cells (Tiemann et al., 2003). We found the manifest effect of ZEA on post-weaning piglets during clinical practice and therefore the studies were performed using post-weaning gilts. Several measurements of genital organs in document were induced by high ZEA concentrations, but such high levels of ZEA are not common in cereals used for animals (Zinedine et al., 2007). Zearalenone levels used in the present study were based on our investigations in Shandong Province of China from June 2007 to May 2012 and recent literature (Zinedine et al.,

Copyright $@ 2015$ by Asian-Australasian Journal of Animal Sciences This is an open-access article distributed under the terms of the Creative Commons Attribution Non-Commercial License (http://creativecommons.org/licenses/by-nc/3.0/) which permits unrestricted non-commercial use, distribution, and reproduction in any medium, provided the original work is properly cited. 
2007; Jiang et al., 2011). A 5-year survey program was initiated by our research group in order to evaluate the incidence of ZEA in feed and feed raw materials in Shandong Province of China. A total of 1,389 analyses were performed by the Asia Mycotoxin Analysis Center (Chaoyang University of Technology, Taichung, Taiwan). Results showed that the positive detection rate of ZEA reached $69.15 \%$, the highest value of ZEA in compound feed samples was $4.33 \mathrm{mg} / \mathrm{kg}$ and the average value of ZEA in compound feed samples was $0.97 \mathrm{mg} / \mathrm{kg}$. Whether ZEA at the level of 1.1 to $3.2 \mathrm{mg} / \mathrm{kg}$ will induce the structural abnormalities of genital organs of piglets and result in the damages of the subsequent reproductive ability or not remained to be confirmed. So, systematic information regarding the dose-effect relationship between ZEA (1.1 to $3.2 \mathrm{mg} / \mathrm{kg}$ ) and its reproductive toxicity of weaned piglets is very necessary and significant.

Therefore, an experiment was conducted to examine whether or not feeding ZEA-contaminated (1.1 to 3.2 $\mathrm{mg} / \mathrm{kg}$ ) diet to post-weanling piglets will influence serum hormones, morphologic and apoptotic measurements of genital organs.

\section{MATERIALS AND METHODS}

\section{Preparation of zearalenone contaminated diet}

Purified ZEA (Fermentek, Jerusalem, Israel) was dissolved in acetic ether, and then poured onto talcum powder. A ZEA premix was prepared by blending ZEAcontaminated talcum powder with ZEA-free corn, which was subsequently mixed at the appropriate levels with a corn-soybean meal diet to create the experimental diets. All diets were prepared in one batch, and then stored in covered containers prior to feeding. A composite sample of each experimental diet was prepared for analysis of ZEA and other mycotoxins by the Asia Mycotoxin Analysis Center (Chaoyang University of Technology, Taichung, Taiwan) before and at the end of the feeding experiment. Deoxynivalenol (DON) was analyzed using high performance liquid chromatography. Enzyme linked immunosorbent assay and fluorometry techniques were used to measure ZEA, fumonisins (FUM), and aflatoxin (AFL) levels. The detection limits of these mycotoxins were $1 \mu \mathrm{g} / \mathrm{kg}$ for AFL, $0.1 \mathrm{mg} / \mathrm{kg}$ for ZEA, $0.25 \mathrm{mg} / \mathrm{kg}$ for FUM, and $0.1 \mathrm{mg} / \mathrm{kg}$ for DON, including 3-acetyl DON, 15-acetyl DON, and nivalenol.

\section{Experimental design, female piglets and management}

Animals used in all experiments were cared for in accordance with the guidelines for the care and use of laboratory animals described by the Animal Nutrition Research Institute of Shandong Agricultural University and the Ministry of Agriculture of China. A total of twenty post- weaning female piglets (LandracexYorkshirexDuroc) with an average body weight of $10.36 \pm 1.21 \mathrm{~kg}$ were used in the study. Gilts were randomly allocated into four treatments after seven days of adaptation. Pigs were fed a basal diet (Table 1) supplemented with an addition of $0,1,2$, or 3 $\mathrm{mg} / \mathrm{kg}$ purified ZEA for 18 day. Analyzed ZEA contents were $0,1.1 \pm 0.02,2.0 \pm 0.01$, and $3.2 \pm 0.02 \mathrm{mg} / \mathrm{kg}$ in the control and the three experimental diets, respectively. Aflatoxin, DON, and FUM were not detected in the test diets (Jiang et al., 2011).

Diets used in the study were isocaloric and isonitrogenous with the only difference being ZEA level. All nutrient concentrations were formulated to meet or exceed minimal requirements according to the NRC (1998). Pigs were housed in cages equipped with one nipple drinker and one brick-shaped feeder in a temperature controlled room at Jinzhuyuan Farm (Yinan, Shandong, China). During the experimental period, the temperature in the nursery room was maintained between $26^{\circ} \mathrm{C}$ and $28^{\circ} \mathrm{C}$. The

Table 1. Ingredients and compositions of the basal diet ${ }^{1}$

\begin{tabular}{|c|c|}
\hline \multicolumn{2}{|l|}{ Items } \\
\hline \multicolumn{2}{|l|}{ Ingredients (\%) } \\
\hline Corn & 53.00 \\
\hline Wheat middling & 5.00 \\
\hline Whey powder & 6.50 \\
\hline Soybean oil & 2.50 \\
\hline Soybean neal & 24.76 \\
\hline Fish meal & 5.50 \\
\hline L-lysine $\mathrm{HCl}$ & 0.30 \\
\hline DL-methionine & 0.10 \\
\hline L-threonine & 0.04 \\
\hline Calcium phosphate & 0.80 \\
\hline Limestone, pulverized & 0.30 \\
\hline Sodium chloride & 0.20 \\
\hline Premix $^{2}$ & 1.00 \\
\hline \multicolumn{2}{|c|}{ Nutrients (Analyzed values) } \\
\hline Gross energy (MJ/kg) & 17.12 \\
\hline Crude protein $(\%)$ & 19.40 \\
\hline Calcium $(\%)$ & 0.84 \\
\hline Total phosphorus (\%) & 0.73 \\
\hline Lysine (\%) & 1.36 \\
\hline Methionine (\%) & 0.46 \\
\hline Sulfur amino acid (\%) & 0.79 \\
\hline Threonine $(\%)$ & 0.90 \\
\hline Tryptophan (\%) & 0.25 \\
\hline \multicolumn{2}{|c|}{$\begin{array}{l}\text { ZEA, zearalenone. } \\
{ }^{1} \text { Treatments were basal diet supplemented with ZEA at the level of } 0,1 \text {, } \\
\text { 2, or } 3 \mathrm{mg} / \mathrm{kg} \text {, with analyzed ZEA concentrations of } 0,1.1,2.0 \text {, and } 3.2 \\
\mathrm{mg} / \mathrm{kg} \text {, respectively. } \\
{ }^{2} \text { Supplied per kg of diet: vitamin A, } 3,300 \mathrm{IU} \text {; vitamin } \mathrm{D}_{3} \text {, } 330 \mathrm{IU} \text {; } \\
\text { vitamin E, } 24 \mathrm{IU} \text {; vitamin } \mathrm{K}_{3}, 0.75 \mathrm{mg} \text {; vitamin } \mathrm{B}_{1}, 1.50 \mathrm{mg} \text {; vitamin } \mathrm{B}_{2} \text {, } \\
5.25 \mathrm{mg} \text {; vitamin } \mathrm{B}_{6}, 2.25 \mathrm{mg} \text {; vitamin } \mathrm{B}_{12}, 0.02625 \mathrm{mg} \text {; pantothenic } \\
\text { acid, } 15.00 \mathrm{mg} \text {; niacin, } 22.5 \mathrm{mg} \text {; biotin, } 0.075 \mathrm{mg} \text {; folic acid, } 0.45 \mathrm{mg} \text {; } \\
\text { Mn, } 6.00 \mathrm{mg} ; \mathrm{Fe}, 150 \mathrm{mg} \text {; } \mathrm{Zn}, 150 \mathrm{mg} \text {; } \mathrm{Cu}, 9.00 \mathrm{mg} \text {; I, } 0.21 \mathrm{mg} \text {; Se, } 0.45 \\
\text { mg. }\end{array}$} \\
\hline
\end{tabular}


mean relative humidity was approximately $65 \%$. The gilts were fed ad libitum and allowed access to water freely through the entire experiment period.

\section{Sample collection}

Piglets were fasted for $12 \mathrm{~h}$ at the end of the experimental period. Proximally $10 \mathrm{~mL}$ blood samples were collected from the jugular vein of all animals into nonheparinized tube and incubated at $37^{\circ} \mathrm{C}$ for $2 \mathrm{~h}$, centrifuged subsequently at $1,500 \times \mathrm{g}$ for $10 \mathrm{~min}$ and the serum was stored in $1.5 \mathrm{~mL}$ Eppendorf tubes at $-20^{\circ} \mathrm{C}$ for hormone analyses described below. After the collection of blood samples, piglets were immediately euthanized, and genital organs (ovary+cornu uteri+vagina-vestibule) were isolated, weighed, and gross lesions examined. Two samples of ovary and cornu uteri tissues from each pig were quickly collected and fixed promptly in $10 \%$ buffered formalin, one portions for morphologic evaluation, and the second for apoptotic measurements.

\section{Determination of serum hormones}

Serum content of testosterone, progesterone, estradiol, luteinizing hormone, follicle stimulating hormone (FSH) and prolactin was assayed by radioimmunoassay (RIA) using commercial RIA Kit (Nanjing Jiancheng Bioengineering Institute, Nanjing, China) according to the manufacturer's protocol with SN-682RIA gamma counter (Shanghai Fuguang nuclear Photoelectric Instrument Co. Ltd., Shanghai, China). Hormone levels per piglet were determined in triplicate tubes to avoid inter-assay variation (Jiang et al., 2012).

\section{Morphologic tests}

Ovary and cornu uteri tissues fixed in $10 \%$ buffered formalin were embedded in paraffin after routine processing. For general orientation the tissues were sectioned in pieces of $5 \mu \mathrm{m}$ thickness and stained with hematoxylin and eosin for microscopy examination. Five slides with minimum of 20 fields of view from each piglet were randomly selected for evaluation using an optical microscope (Zeiss, Hallbergmoos, Germany).

\section{Terminal-deoxynucleotidyl transferase mediated nick end labeling assay}

To evaluate cell death by apoptosis, the In Situ Apoptosis Detection Kit (Nanjing Jiancheng Bioengineering Institute, Nanjing, China) was used according to the manufacturer's instructions. Briefly, dewaxed tissue sections were predigested with $20 \mathrm{mg} / \mathrm{mL}$ proteinase $\mathrm{K}$ for $20 \mathrm{~min}$ and then incubated in phosphatebuffered saline (PBS) containing $3 \% \mathrm{H}_{2} \mathrm{O}_{2}$ /methanol for 10 min. Following washing with $\mathrm{PBS}$, tissues were permeabilized in $0.2 \%$ Triton $\mathrm{X}-100 / \mathrm{PBS}$ for 2 min at $4^{\circ} \mathrm{C}$.
After $50 \mu \mathrm{L}$ reaction buffer containing TdT enzyme $(45 \mu \mathrm{L}$ equilibration buffer+1 $\mu \mathrm{L}$ Biotin-11-dUTP+4 $\mu \mathrm{L}$ TdT Enzyme) was added, samples were moistly incubated under the coverslip at $37^{\circ} \mathrm{C}$ for 60 minutes, without TdT enzymes on the negative slide. Following all slides rinsing three times in PBS, $50 \mu \mathrm{L}$ working solution containing Streptavidin-horseradish peroxidase (HRP) $\quad(0.5 \mu \mathrm{L}$ Streptavidin-HRP+99.5 $\mu \mathrm{L}$ PBS) was added and all slides were moistly incubated under the coverslip at $37^{\circ} \mathrm{C}$ for 30 minutes. The samples were incubated for $10 \mathrm{~min}$ with $100 \mu \mathrm{L}$ diaminobenzidine (DAB) substrate $(5 \mu \mathrm{L} 20 \%$ DAB $+1 \mu \mathrm{L} \mathrm{30 \%} \mathrm{H}_{2} \mathrm{O}_{2}+94 \mu \mathrm{L}$ PBS) in the dark after rinsing in PBS three times, and then all slides were re-stained routinely with hematoxylin. At the end, the samples were mounted and analyzed under light microscope (Zeiss, Hallbergmoos, Germany), where the apoptotic cells could be seen as shrunken dark brown cells and the normal ones blue-purple. The calculation method used is as follows: apoptotic index $(\mathrm{AI})=($ number of apoptotic cells/total number of observed cells $) \times 100 \%$.

\section{Statistical analyses}

Data of serum hormones were subjected to analysis of variance using the general linear model procedure of SAS (2003). The data were first analyzed as a completely randomized design with individual piglet as random factor to examine the overall effect of treatments. Orthogonal polynomial contrasts were then used to determine linear and quadratic responses to ZEA levels of treatments. The significance differences of serum hormones among treatments were tested using Duncan's multiple range tests. All statements of significance were based on the probability of $\mathrm{p}<0.05$.

\section{RESULTS}

\section{Serum hormones}

Serum hormones were analyzed as an index of an endocrine disrupter of ZEA with effects on piglets (Table 2). $3.2 \mathrm{mg} / \mathrm{kg}$ ZEA challenged gilts had decreased $(\mathrm{p}<0.05)$ serum levels of luteinizing hormone, however, serum levels of prolactin in gilts fed the diet containing $2.0 \mathrm{mg} / \mathrm{kg} \mathrm{ZEA}$ or more were increased $(\mathrm{p}<0.05)$ compared to those in the control. Linear effects on all tested serum hormones except progesterone and quadratic effects on serum luteinizing hormone and prolactin were observed as dietary ZEA levels increased $(\mathrm{p}<0.05)$.

\section{Morphologic examination}

Based on the observations after slaughter, the reproductive organs in the ZEA treatment groups, especially those in the treatment group with $3.2 \mathrm{mg} / \mathrm{kg}$ of ZEA, were shown to be significantly larger than those in the control 
Table 2. Serum hormones of gilts fed diet with or without zearalenone supplementation ${ }^{1}$

\begin{tabular}{lccccccc}
\hline Items & \multirow{2}{*}{ Contr. } & \multirow{2}{*}{ ZEA1 } & \multirow{2}{*}{ ZEA2 } & \multirow{2}{*}{ ZEA3 } & \multirow{2}{*}{ SEM } & \multicolumn{2}{c}{ Effects (p values) } \\
\cline { 5 - 8 } & & 5.80 & 5.28 & 5.11 & 4.87 & 0.056 & 0.138 \\
Testosterone $(\mathrm{ng} / \mathrm{dL})$ & 0.35 & 0.25 & 0.29 & 0.24 & 0.006 & 0.108 & 0.020 \\
Progesterone $(\mathrm{ng} / \mathrm{mL})$ & 20.85 & 19.52 & 17.49 & 16.38 & 0.278 & 0.123 & 0.014 \\
Estradiol $(\mathrm{pg} / \mathrm{mL})$ & $8.08^{\mathrm{a}}$ & $7.57^{\mathrm{ab}}$ & $7.52^{\mathrm{ab}}$ & $6.74^{\mathrm{b}}$ & 0.066 & 0.049 & 0.009 \\
Luteinizing hormone $(\mathrm{mIU} / \mathrm{mL})$ & 14.69 & 14.45 & 13.41 & 12.45 & 0.157 & 0.180 & 0.028 \\
Follicle stimulating hormone $(\mathrm{mIU} / \mathrm{mL})$ & $22.35^{\mathrm{c}}$ & $22.59^{\mathrm{bc}}$ & $23.69^{\mathrm{b}}$ & $25.45^{\mathrm{a}}$ & 0.085 & $<0.001$ & $<0.001$ \\
Prolactin $(\mathrm{ng} / \mathrm{mL})$ & & & & &
\end{tabular}

ZEA, zearalenone; SEM, standard error of the means.

${ }^{1}$ Data are means for 5 replicates per treatment. Data per piglet were run in triplicate in a single assay to avoid inter-assay variation.

Zearalenone was not detectable in control diet; ZEA1, ZEA2 or ZEA3 represents control diet with addition of 1.1, 2.0, or 3.2 mg/kg zearalenone, respectively.

${ }^{a, b, c}$ Means within a row with different letters differ significantly $(\mathrm{p}<0.05)$.

group (Figure 1).

In the control group, a large number of ovarian follicles at different developmental stages in the cortex were visible at low magnification. There were many primordial follicles (red arrows) and lesser primary growing follicles (blue arrows), but no mature follicles were observed (Figure 2). In the treatment group with $1.1 \mathrm{mg} / \mathrm{kg}$ of ZEA, the developing primordial follicles were observed in the cortex, oocytes became bigger and had a regular shape with oval or round, but no atretic follicle (green arrows) was present. The numbers of primordial follicles and primary growing

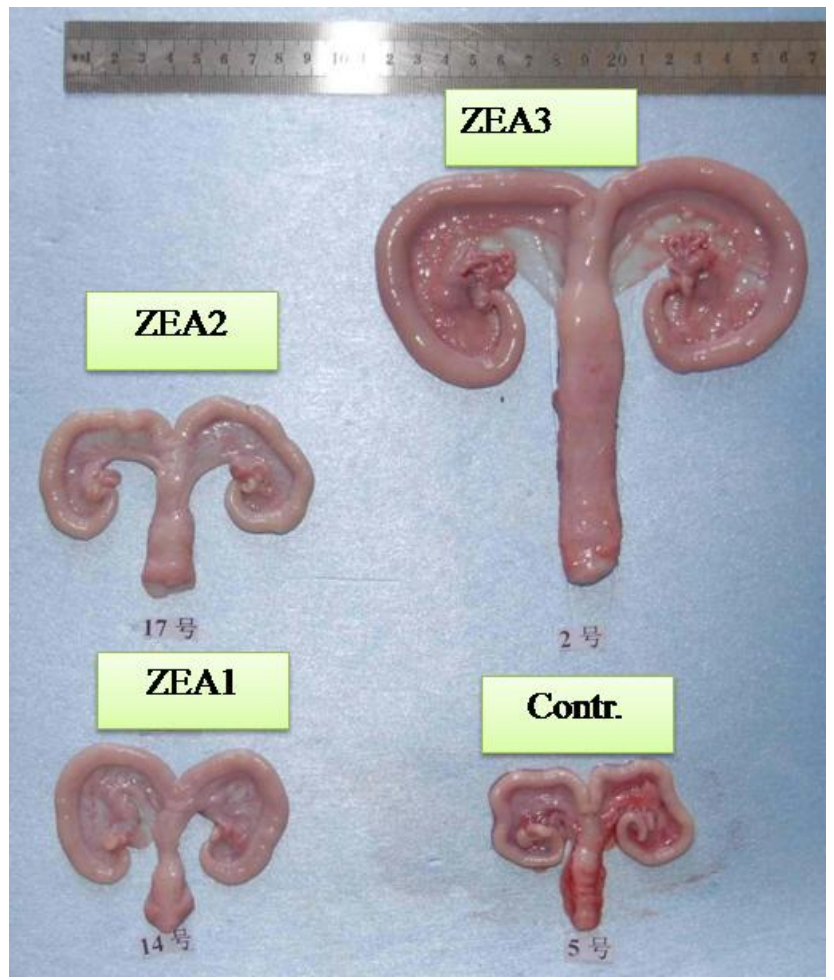

Figure 1. Effects of different levels of zearalenone on genital organs (ovary+cornu uteri+vagina-vestibule) of gilts. Zearalenone was not detectable in control diet; ZEA1, ZEA2, or ZEA3 represents control diet with addition of $1.1,2.0$, or $3.2 \mathrm{mg} / \mathrm{kg}$ ZEA, respectively. ZEA, zearalenone. follicles observed in the cortex were significantly lower in the treatment groups with 2.0 and $3.2 \mathrm{mg} / \mathrm{kg}$ of ZEA than those in the control group at low magnification. Oocytes of primordial follicle proceeded with atrophy or degeneration, and atresic follicles were observed at high magnification in $3.2 \mathrm{mg} / \mathrm{kg}$ ZEA treatment.

Changes of morphologic structure in the corpus uteri were reflected in the mucosal epithelium (red arrows), lamina propria (blue arrows) and muscular layer (green arrows) among all tested groups (Figure 3). The mucosal epithelium was composed of simple columnar epithelium in both control and the $1.1 \mathrm{mg} / \mathrm{kg}$ ZEA treatment, but thicker lamina propria was observed in the $1.1 \mathrm{mg} / \mathrm{kg}$ ZEA treatment than those in the control. The mucosal epithelium became stratified epithelium in both 2.0 and 3.2 $\mathrm{mg} / \mathrm{kg}$ ZEA treatment, and the thickness of lamina propria was increased in dose-dependent manner. Obvious changes in the muscular layer were also reflected by significantly increased smooth muscle bundles (green arrows) in both 2.0 and $3.2 \mathrm{mg} / \mathrm{kg}$ ZEA treatment.

\section{Apoptotic examination}

In the observations of ovarian apoptosis, a large number of apoptotic cells (brown, $\mathrm{AI}=60 \%$ to $85 \%$ ) in granulosa were visible at high magnification in the control group. The apoptotic cells in the treatment group with $1.1 \mathrm{mg} / \mathrm{kg}$ of ZEA ( $\mathrm{AI}=20 \%$ to $35 \%$ ) were significantly fewer in number than those in the control group, while a large number of normal cells (blue-purple, $\mathrm{AI}=0$ ) were visible in the treatment groups with $2.2 \mathrm{mg} / \mathrm{kg}$ and $3.2 \mathrm{mg} / \mathrm{kg}$ of ZEA, without apoptotic cells (Figure 4).

No apoptotic cells in granulosa were found in the corpus uteri at high magnification in both control and the ZEA treatment groups (data not shown).

\section{DISCUSSION}

The similar growth rate, feed intake, and feed efficiency of the piglets among all the treatments indicated that gilts 


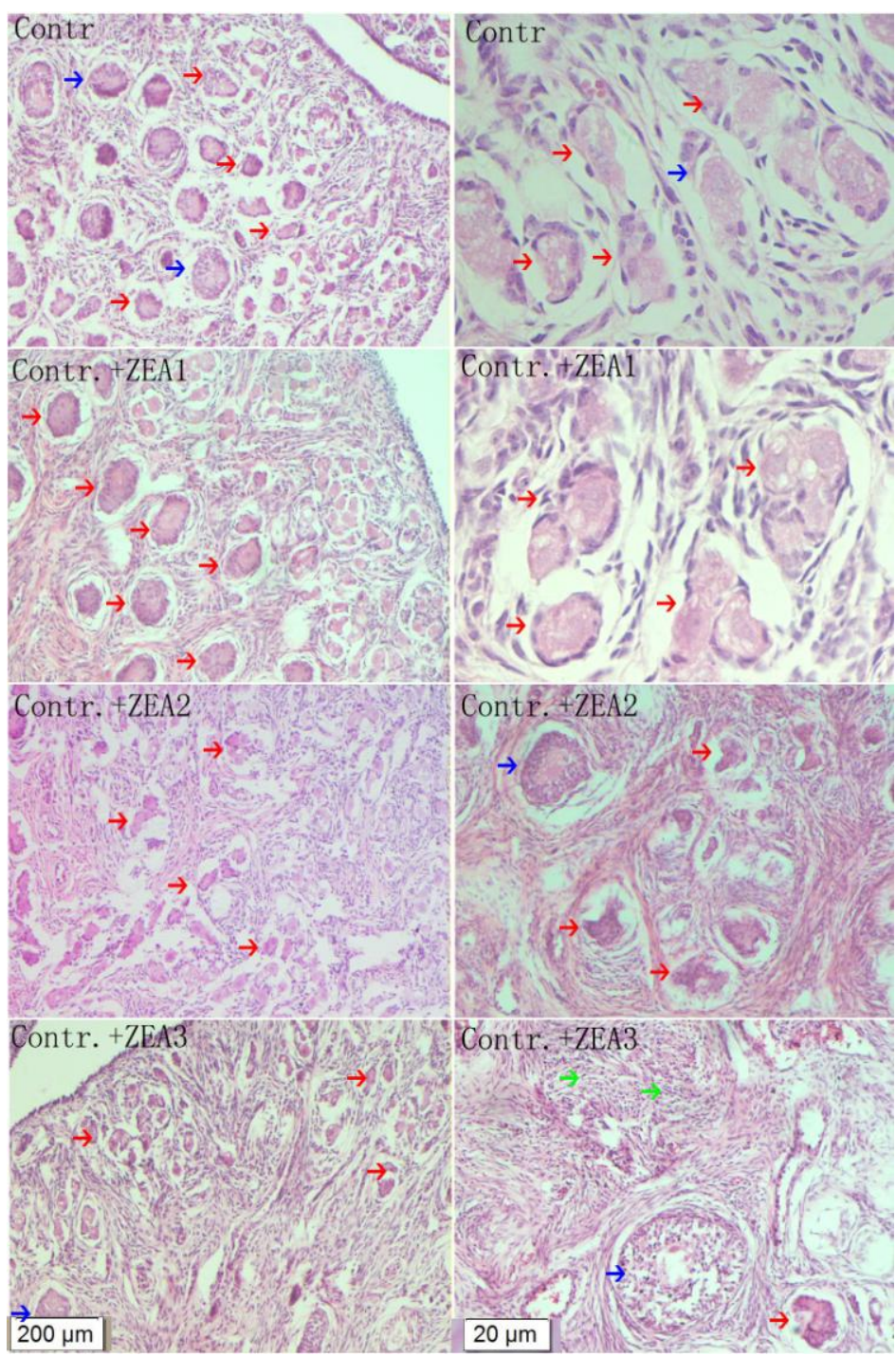

Figure 2. Effects of different levels of zearalenone on photomicrographs of hematoxylin and eosin stained ovary sections of gilts. Zearalenone was not detectable in control diet; ZEA1, ZEA2, or ZEA3 represents control diet with addition of $1.1,2.0$, or 3.2 mg/kg ZEA, respectively. Red, blue or green arrows represent the primordial follicle, primary growth follicles or atresic follicle, respectively. ZEA, zearalenone.

within a treatment likely consumed a similar amount of ZEA, and that differences obtained among treatments were likely attributable to the different concentrations of ZEA in the diet (Jiang et al., 2011).

Success in observing the effect of ZEA-contaminated diets on serum hormones, changes of morphologic structure of genital organs, and anti-apoptotic effect on ovarian granulosa cells in the current study may be very significant. ZEA could interfere with the synthesis and metabolism of steroid hormones by interacting with estrogen receptors in testis (LeBlanc et al., 1997), which played the role of transcription factor in cell growth, proliferation and differentiation. Due to the activation of estradiol receptors, mycotoxins with an estrus effect interfered with normal hormonal signals, resulting in endocrine disturbance (Mueller et al., 2004). ZEA caused the disruption of the hypothalamic-pituitary-ovarian axis (Rainey et al., 1990), as well as suppressed the secretion of FSH in the ovaries (Silva et al., 2004), which was consistent with the results that the serum FSH level decreased linearly with the increase in dietary ZEA in the present study. After 70-dayold male rats were fed a diet containing ZEA $(20 \mathrm{mg} / \mathrm{kg}$ of body weight/d) for five weeks, serum prolactin levels increased significantly (Milano et al., 1995), which was also consistent with the results in the present study. Kaliamurthy et al. (1997) reported that the mature male rats (Wistar strain) showed a significant decrease in serum testosterone level after being fed a diet containing ZEA $(0.25 \mathrm{mg} / \mathrm{kg}$ of body weight/d) by means of gastric intubation. Yang et al. (2007) indicated that ZEA and $\alpha$-zearalenol $\left(10^{-4} \mathrm{M}, 10^{-6} \mathrm{M}\right.$, and $10^{-8} \mathrm{M}$ ) significantly inhibited human chorionic gonadotropin-induced testosterone secretion, and this 


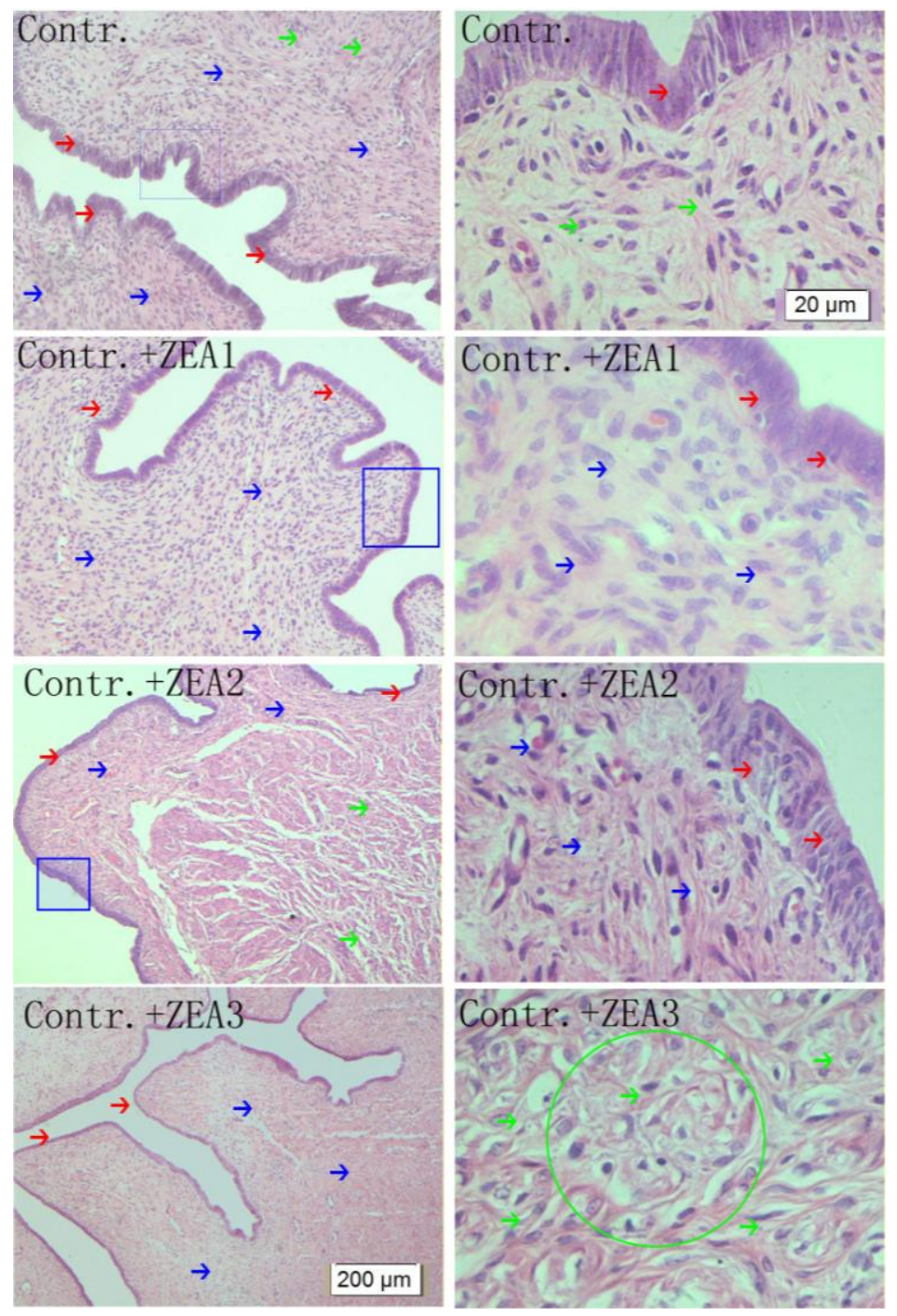

Figure 3. Effects of different levels of zearalenone on photomicrographs of hematoxylin and eosin stained corpus uteri sections of gilts. Zearalenone was not detectable in control diet; ZEA1, ZEA2, or ZEA3 represents control diet with addition of 1.1, 2.0, or 3.2 mg/kg ZEA, respectively. Red, blue or green arrows represent the mucosal epithelium, lamina propria or muscular layer, respectively. ZEA, zearalenone.

inhibition was associated with the decreased transcription of $3 \beta$-hydroxy-steroid dehydrogenase, cytochrome P450 side chain cleavage enzymes, and steroidogenic acute regulatory proteins. Minervini et al. (2001) showed that ZEA, $\alpha$ zearalenol, and zearalanol $(0.3$ to $30 \mu \mathrm{g} / \mathrm{mL})$ altered the $17 \beta$-estradiol level in the in vitro culture supernatant of bovine oocytes with dose-dependence. It had also been found that, as a competitive substrate for the enzymes involved in the synthesis and metabolism of steroids, ZEA caused endocrine disturbance; in addition, $\alpha-$ and $\beta$ zearalenol affected progesterone synthesis in cultured porcine granulosa cells (Tiemann et al., 2003). Based on the above studies, it was suggested that the effects of ZEA on endocrine depend on sex, age and dose. Nevertheless, the positive effect of ZEA on serum hormones in the present study further demonstrated the estrogen effect of ZEA.
ZEA and $\alpha$-zearalenol could competitively bind to $17 \beta$ estradiol, inducing hyperestrogenism (Yang et al., 1994; Alexopoulos, 2001) and subsequently activating gene expression of nuclear RNA polymerase I and II, and the synthesis of new proteins (Ueno, 1991), thus causing germ cell proliferation and ultimately resulting in swollen vulva and enlarged uterus as in the present study. Atrophic or degenerative ovarian follicles, uterine atrophy, pyometra and endometritis were found in minks with ZEA feeding $(20 \mathrm{mg} / \mathrm{kg})$ by histopathological examination of reproductive tract (Yang et al., 1994). Wasowicz et al. (2005) reported that atretic follicles in the ovarian cortex of prepubertal gilts were observed in the treatment with $40 \mu \mathrm{g}$ ZEA $/ \mathrm{kg}$ body weight. Jiang et al. (2010) demonstrated that a dose of ZEA at $1.3 \mathrm{mg} / \mathrm{kg}$ was capable of causing inflammation and allergies in the ovary of post-weaning 

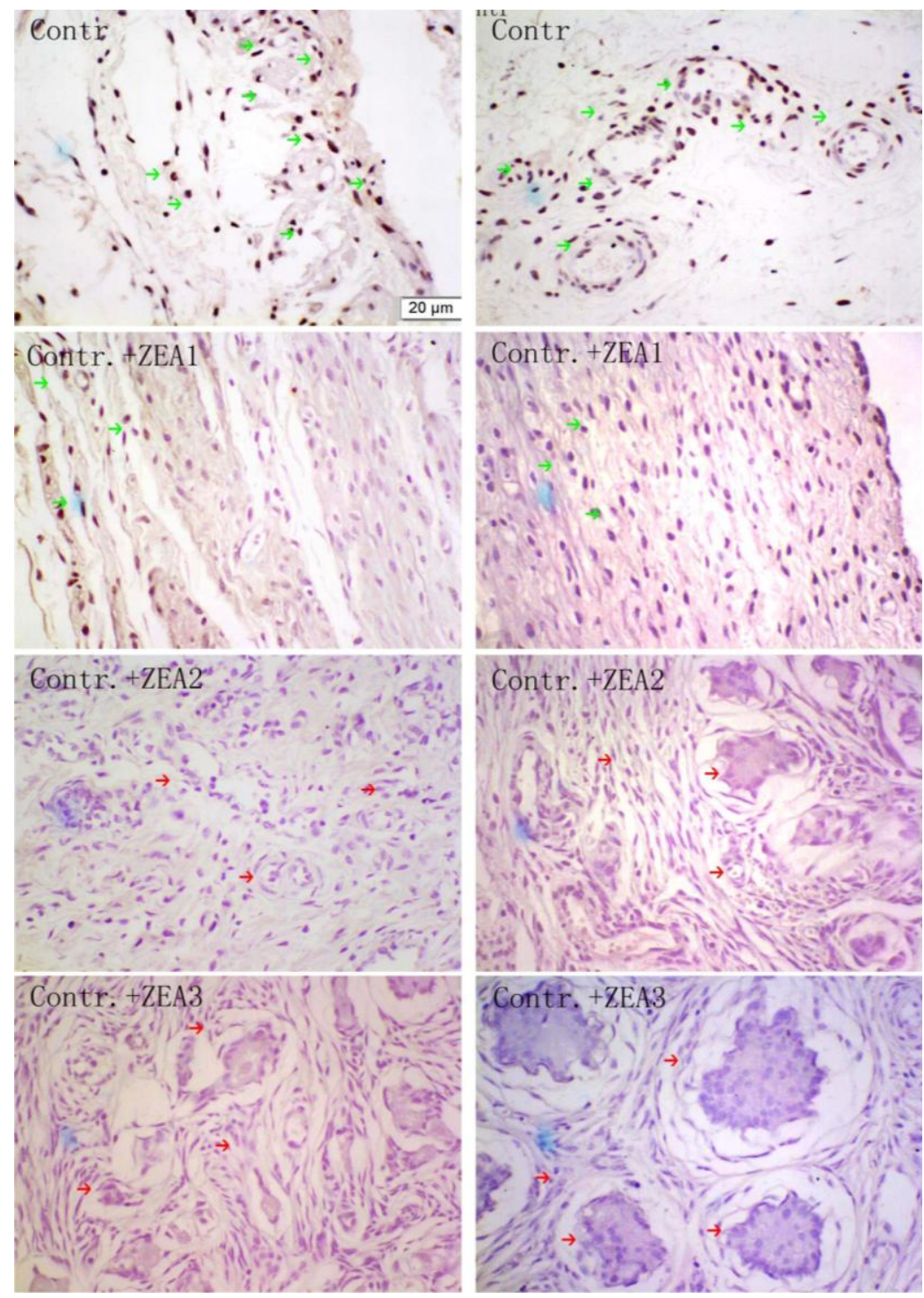

Figure 4. Effects of different levels of zearalenone on apoptotic photomicrographs of ovary sections of gilts (diaminobenzidine and hematoxylin, 400× original magnification). Zearalenone was not detectable in control diet; ZEA1, ZEA2, or ZEA3 represents control diet with addition of $1.1,2.0$, or $3.2 \mathrm{mg} / \mathrm{kg}$ ZEA, respectively. The apoptotic cell was brown (green arrows) and the normal cell was bluepurple (red arrows). ZEA, zearalenone.

gilts. Vulva size and the relative weight of genital organs increased linearly over the $18 \mathrm{~d}$ feeding in gilts fed diets containing $1.1 \mathrm{mg} / \mathrm{kg}$ ZEA or greater compared with the control (Jiang et al., 2011). In the present study, ZEA at the level of $1.1 \mathrm{mg} / \mathrm{kg}$ stimulated follicular development. Numerous remnant of atresic follicles were observed in cortex in the treatment groups with 2.0 and $3.2 \mathrm{mg} / \mathrm{kg}$ ZEA, and the reason was that the ZEA at the level of 2.0 and 3.2 $\mathrm{mg} / \mathrm{kg}$ caused the rapid development of primordial follicles and the formation of atresic follicle in a short time, so as no ovarian follicle was visible. ZEA could affect uterine development and alter the morphological structure of uterine tissues by reducing the secretion of luteinizing hormones and progesterone (Etienne and Dourmad, 1994). But whether ZEA at the level of $1.1 \mathrm{mg} / \mathrm{kg}$ early consumed the ovarian follicle and resulted in the damages of the following reproductive ability or not remains to be confirmed. So, the mechanism of the above presumption needs to be validated in a following study.

In a series of recent studies, it had been reported that ZEA had a proliferative effect on uterine cells in female piglets, but interfered with the development and maturation of ovarian follicles, and with follicular atresia and granulosa cell apoptosis (Obremski et al., 2003; Zwierzchowski et al., 2005). The decreased numbers of apoptotic granulosa cells in the ovary were observed in gilts treated with ZEA in a dose-dependent manner in the present study. These findings suggested that 1.1 to $3.2 \mathrm{mg} / \mathrm{kg}$ of ZEA have an antiapoptotic effect on ovarian granulosa cells. Wasowicz et al. (2005) demonstrated that the apoptotic signal was detected 
in the granular layer of the cystic ovarian follicles in the control and treatment with ZEA at the level of $20 \mu \mathrm{g} / \mathrm{kg}$ of body weight/d, but not in the treatment with ZEA at the level of $40 \mu \mathrm{g} / \mathrm{kg}$ of body weight $/ \mathrm{d}$, which was consistent with the results of the present study. Yu et al. (2005) indicated that ZEA-mediated anti-apoptotic effect was resultant of the fact that ZEA up-regulated the expression of anti-apoptotic gene $\mathrm{Bcl}-2$, while down-regulated the expression of pro-apoptotic gene Bak in the levels of protein and mRNA. No anti-apoptotic effect on uterine cells by ZEA treated suggested that the expression of antiapoptotic gene $\mathrm{Bcl}-2$ in the uterus might be significantly lesser than those in the ovary, which needs to be verified further. This presumption was consistent with smooth muscle hyperplasia seen in the tissue section of the corpus uteri. However, Gajęcka et al. (2011) showed that immature gilts fed with ZEA at the level of $20 \mu \mathrm{g} / \mathrm{kg}$ body weight lowered the proliferative ability of granulosa cells in the ovarian follicle walls. The above results indicated that the effects of ZEA on reproductive organs were associated with the test method, experimental material, organ type and dose of ZEA. However, the relationship of the anti-apoptotic and serum hormones levels caused by ZEA needs to be verified further.

\section{CONCLUSION}

The current study demonstrated that ZEA feeding at 1.1 to $3.2 \mathrm{mg} / \mathrm{kg}$ for $18 \mathrm{~d}$ induced different degrees of toxicity in genital organs of post-weaning gilts as indicated by the changes in serum hormones, morphologic and apoptotic examinations tested in this study. Mostly the parameters were linearly affected as dietary ZEA concentrations increased. The study further showed that there may be another pathway of apoptosis for the toxicity to occur in the genital organs of gilts fed ZEA contaminated feeds. More cellular and molecular studies are needed to understand ZEA biological mode of actions and the toxicity of ZEA thoroughly.

\section{ACKNOWLEDGMENTS}

This research was financed by the special funds of the construction of the modern agricultural industry technology system for the pig industry of Shandong Province and Amlan International, a division of OIL-DRI Corporation of America (Chicago, IL, USA). The authors wish to thank Dr. Chia Chung Chen at Chaoyang University of Technology, Taiwan, for his assistance on mycotoxins analysis and general chemistry consultations.

\section{REFERENCES}

Alexopoulos, C. 2001. Association of Fusarium mycotoxicosis with failure in applying an induction of parturition program with PGF2-alpha and oxytocin in sows. Theriogenology 55:1745-1757.

Blaney, B. J., R. C. Bloomfield, and C. J. Moore. 1984. Zearalenone intoxication of pigs. Aust. Vet. J. 61:24-27.

Chang, K., H. J. Kurtz, and C. J. Mirocha. 1979. Effects of the mycotoxin zearalenone on swine reproduction. Am. J. Vet. Res. 40:1260-1267.

Chaytor, A. C., J. A. Hansen, E. van Heugten, M. T. See, and S. W. Kim. 2011. Occurrence and decontamination of mycotoxins in swine feed. Asian Australas. J. Anim. Sci. 24:723-738.

Etienne, M. and M. Jemmali. 1982. Effects of zearalenone (F2) on estrous activity and reproduction in gilts. J. Anim. Sci. 55:1-10.

Etienne, M. and J. Y. Dourmad. 1994. Effects of zearalenone or glucosinolates in the diet on reproduction in sows: A review. Livest. Prod. Sci. 40:99-113.

EFSA. 2004. Opinion of the Scientific Panel on Contaminants in the Food Chain on a request from the Commission related to zearalenone as undesirable substance in animal feed. EFSA J. 89:1-35.

Gajecka, M., L. Rybarczykb, W. Zwierzchowskia, E. Jakimiuka, L. Zielonkaa, K. Obremskia, and M. Gajecki. 2011. The effect of experimental, long-term exposure to low-dose zearalenone mycotoxicosis on the histological condition of ovaries in sexually immature gilts. Theriogenology 75:1085-1094.

Jiang, S. Z., Z. B. Yang, W. R. Yang, B. Q .Yao, H. Zhao, F. X. Liu, C. C. Chen, and F. Chi. 2010. Effects of feeding purified zearalenone contaminated diets with or without clay enterosorbent on growth, nutrient availability, and genital organs in post-weaning female pigs. Asian Australas. J. Anim. Sci. 23:74-81.

Jiang, S. Z., Z. B. Yang, W. R. Yang, J. Gao, F. X. Liu, J. Broomhead, and F. Chi. 2011. Effects of purified zearalenone on growth performance, organ size, serum metabolites, and oxidative stress in postweaning gilts. J. Anim. Sci. 89:30083015.

Jiang, S. Z., Z. B. Yang, W. R. Yang, S. J. Wang, F. X. Liu, L. A. Johnston, F. Chi, and Y. Wang. 2012. Effect of purified zearalenone with or without modified montmorillonite on nutrient availability, genital organs and serum hormones in post-weaning piglets. Livest. Sci. 144:110-118.

Kaliamurthy, J., P. Geraldine, and P. A. Thomas. 1997. Effects of Zearalenone on food consumption, growing rate, organ weight and serum testosterone level in male rats. J. Environ. Biol. 18:115-120.

LeBlanc, G. A., L. J. Bain, and V. S. Wilson. 1997. Pesticides: multiple mechanisms of demasculinization. Mol. Cell Endocrinol. 126:1-5.

Milano, G. D., D. Becu-Villalobos, and M. O. Tapia. 1995. Effects of long-term zearalenone administration on spermatogenesis and serum luteinizing hormone, follicle-stimulating hormone, and prolactin values in male rats. Am. J. Vet. Res. 56:954-958.

Minervini, F., M. E. Dell Aquila, F. Maritato, P. Minoia, and A. Visconti. 2001. Toxic effects of the mycotoxin zearalenone and its derivatives on in vitro maturation of bovine oocytes and 17 Beta-estradiol levels in mural granulosa cell cultures. Toxicol. In Vitro 15:489-495.

Mitak, M., T. Gojmerac, B. Mandic, and Z. Cvetnic. 2001. Changes in serum concentration of 17-beta estradiol in female 
rats during estrous cycle after treatment with atrazine and zearalenone. Vet. Med. 46:145-148.

Mueller, S. O., S. Simon, K. Chae, M. Metzler, and K. S. Korach 2004. Phytoestrogens and their human metabolites show distinct agonistic and antagonistic properties on estrogen receptor a $\left(\mathrm{ER}_{\alpha}\right)$ and $\mathrm{ER}_{\beta}$ in human cells. Toxicol. Sci. 80:1425.

NRC (National Research Council). 1998. Nutrient Requirements of Swine. 10th ed. National Academy Press, Washington, DC, USA.

Obremski, K., M. Gajecki, W. Zwierzchowski, L. Zielonka, I. Otrocka-Domagala, T. Rotkiewicz, A. Mikołajczyk, M. Gajecka, and M. Polak. 2003. Influence of zearalenone on reproductive system cell proliferation in gilts. Pol. J. Vet. Sci. 6:239-245.

Price, W. D., R. A. Lowell, and D. G. McChsney. 1993. Naturally occurring toxins in feedstuffs: Center for Veterinary Medicine Perspective. J. Anim. Sci. 71:2556-2562.

Rainey, M. R., R. C. Tubbs, L. W. Bennett, and N. M. Cox. 1990 Prepubertal exposure to dietary zearalenone alters hypothalamo-hypophysial function but does not impair postpubertal reproductive function of gilts. J. Anim. Sci. 68:2015-2022.

SAS Institute. 2003. SAS/STAT User's Guide: Version 9.1th ed. SAS Institute Inc., Cary, NC, USA.

Silva, J. R. V., R. van den Hurk, M. H. T. de Matos, R. R. dos Santos, C. Pessoa, M. O. de Moraes, and J. R. de Figueiredo. 2004. Influences of FSH and EGF on primordial follicles during in vitro culture of caprine ovarian cortical tissue. Theriogenology 61:1691-1704.

Tiemann, U., W. Tomeka, F. Schneider, and J. Vanselowb. 2003. Effects of the mycotoxins $\alpha$ - and $\beta$-zearalenol on regulation of progesterone synthesis in cultured granulosa cells from porcine ovaries. Reprod. Toxicol. 17:673-681.
Ueno, Y. 1991. Biochemical mode of action of mycotoxins. In: Mycotoxins and Animal Foods (Eds. J. E. Smith and R. S. Henderson). CRS Press, Boston, MA, USA. p. 437-453.

Wasowicz, K., M. Gajecka, J. Calkal, E. Jakimiuk, and M. Gajecki. 2005. Influence of chronic administration of zearalenoneon on the processes of apoptosis in the porcine ovary. Vet. MedCzech. 50:531-536.

Yang, H. H., R. J. Aulerich, W. Helferich, B. Yamini, K. C. Chou, E. R. Miller, and S. J. Bursian. 1995. Effects of zearalenone and/or tamoxifen on swine and mink reproduction. J. Appl. Toxicol. 15:223-232.

Yang, J., Y. Zhang, Y. Wang, and S. Cui. 2007. Toxic effects of zearalenone and $\alpha$-zearalenol on the regulation of steroidogenesis and testosterone production in mouse Leydig cells. Toxicol. In Vitro 21:558-565.

Yu, Z., L. Zhang, D. Wu, and F. Liu. 2005. Anti-apoptotic action of zearalenone in MCF-7 cells. Ecotoxicol. Environ. Saf. 62:441-446.

Zhang, H., H. Nagasshima, and T. Goto. 1997. Natural occurrence of mycotoxins in corn, samples from high and low risk areas for human esophageal cancer in China. Mycotoxin 44:29-35

Zinedine, A., J. M. Soriano, J. C. Moltó, and J. Manes. 2007. Review on the toxicity, occurrence, metabolism, detoxification, regulations and intake of zearalenone: An oestrogenic mycotoxin. Food Chem. Toxicol. 45:1-18.

Zwierzchowski, W., M. Przybylowcz, K. Obremski, L. Zielonka, E. Skorska-Wyszynska, M. Gajecka, M. Polak, E. Jakimiuk, B. Jana, L. Rybarczyk, and M. Gajecki. 2005. Level of zearalenone in blood serum and lesions in ovarian follicles of sexually immature gilts in the course of zearalenone micotoxicosis. Pol. J. Vet. Sci. 8:209-218. 